University of Nebraska - Lincoln

DigitalCommons@University of Nebraska - Lincoln

Papers in the Earth and Atmospheric Sciences Earth and Atmospheric Sciences, Department

4-2004

\title{
Tropical Westerlies over Pangaean Sand Seas
}

David B. Loope

University of Nebraska, Lincoln, dloope1@unl.edu

Maureen B. Steiner

University of Wyoming

Clinton M. Rowe

University of Nebraska-Lincoln, crowe1@unl.edu

Nicholas Lancaster

University of Nevada, Reno

Follow this and additional works at: https://digitalcommons.unl.edu/geosciencefacpub

Part of the Earth Sciences Commons

Loope, David B.; Steiner, Maureen B.; Rowe, Clinton M.; and Lancaster, Nicholas, "Tropical Westerlies over Pangaean Sand Seas" (2004). Papers in the Earth and Atmospheric Sciences. 247.

https://digitalcommons.unl.edu/geosciencefacpub/247

This Article is brought to you for free and open access by the Earth and Atmospheric Sciences, Department of at DigitalCommons@University of Nebraska - Lincoln. It has been accepted for inclusion in Papers in the Earth and Atmospheric Sciences by an authorized administrator of DigitalCommons@University of Nebraska - Lincoln. 
Published in Sedimentology 51:2 (April 2004), pp. 315-322; doi: 10.1046/j.1365-3091.2003.00623.x

Copyright (C) 2004 International Association of Sedimentologists; published by Wiley-Blackwell. Used by permission.

Submitted April 28, 2003; revision accepted October 24, 2003; published online March 2, 2004.

\title{
Tropical Westerlies over Pangaean Sand Seas
}

\author{
David B. Loope, ${ }^{1}$ Maureen B. Steiner, ${ }^{2}$ Clinton M. Rowe, ${ }^{1}$ and Nicholas Lancaster ${ }^{3}$
}

1. Department of Geosciences, University of Nebraska-Lincoln, Lincoln, NE 68588, USA; email dloope1@unl.edu

2. Department of Geology and Geophysics, University of Wyoming, Laramie, WY 82071, USA

3. Desert Research Institute, University of Nevada, Reno, NV 89512, USA

\begin{abstract}
Cross-equatorial, westerly winds are key features of tropical circulation in monsoonal regions. Although prominent in numerical climate models of Pangaea (the supercontinent straddling earth's equator, Late Paleozoic to Early Mesozoic), such flow has not been confirmed previously by migration directions of ancient dunes. Windblown sandstones that span 100 million years of earth history are widely exposed in south-western USA. If recent paleomagnetic data from the Colorado Plateau are used to correct Mesozoic paleogeographic maps, the Plateau is placed about $10^{\circ}$ further south than previously assumed, and the prevailing north-westerly surface winds recorded by dune-deposited sandstones are explicable as cross-equatorial westerlies - the hallmark of modern monsoon circulation. Permian to Early Jurassic dunes were driven by north-westerlies produced by a steep pressure gradient spanning the supercontinent during December-January-February. Although winds are light in most modern, near-equatorial settings, the East African Jet accounts for more than half the cross-equatorial flow in June-July-August. The thicknesses of annual depositional cycles within the Navajo Sandstone indicate that the near-equatorial, north-westerly winds that drove these particular dunes were stronger than the modern East African Jet. The Early Jurassic dunes that deposited the thick cycles were positioned west of the dominant (southern hemisphere) thermal low and against highlands to the west - a setting very similar to the East African Jet. The mountains along the western coast of Pangaea not only enhanced wind strength, but also cast a rain shadow that allowed active dunes to extend very close to the paleoequator.
\end{abstract}

Keywords: Dunes, Jurassic paleogeography, monsoon, paleowinds, Pangaea

\section{Introduction}

Nearly 2500 m of dune-deposited sandstones accumulated in the south-western United States during the Late Paleozoic and Early Mesozoic (Blakey et al., 1988; Kocurek, 1991). The sandstones are most numerous, thickest and most extensive on the Colorado Plateau (Figure 1). Dip directions that have been compiled from cross-strata within these rocks (Peterson, 1988) present by far the largest paleowind data set for any region or time in earth history. The interpretive value of these data depends on the accuracy with which their paleo- geographic context is known. Even though the centre of the Plateau (here taken as the geographic point common to Utah, Colorado, New Mexico and Arizona) is commonly shown on Early Jurassic paleogeographic maps at about $18^{\circ} \mathrm{N}$ (Parrish \& Peterson, 1988; Peterson, 1988; Scotese, 2003), Colorado Plateau strata have yielded abundant paleomagnetic data that indicate that the Plateau remained in a near-equatorial location from Permian to Early Jurassic time (Steiner, 1983; May \& Butler, 1986; Bazard \& Butler, 1991; Steiner \& Lucas, 2000; Steiner, 2003; Figure 2A). Instead of the steady northward migration shown by the series of maps by 


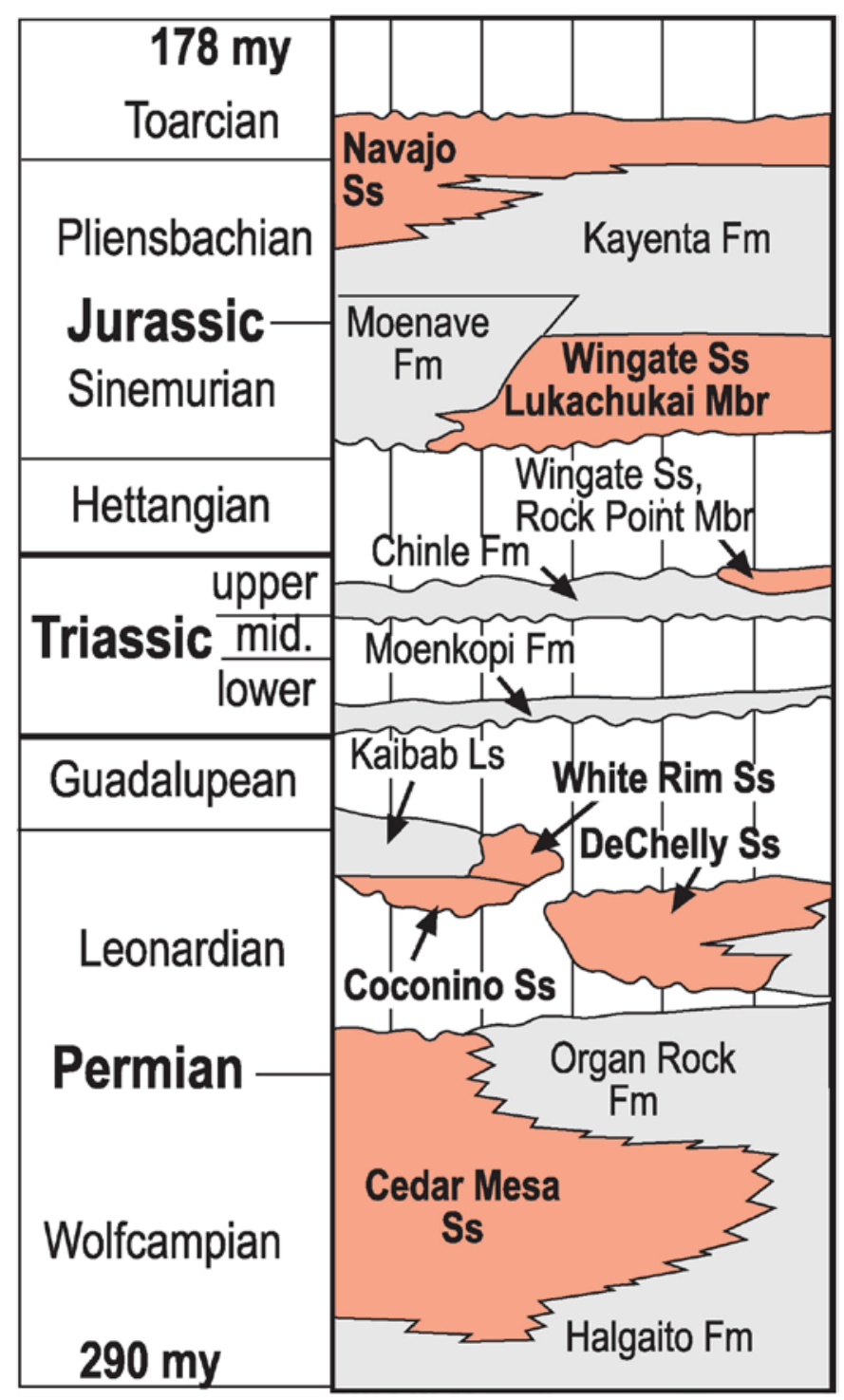

Figure 1. Stratigraphic framework of aeolian sandstones (dark shading) of the Colorado Plateau (modified from Blakey et al., 1988). Time is vertical axis; absolute ages from Harland et al. (1989). Vertical lines delineate time not represented by strata.

Scotese (2003), these paleomagnetic studies indicate a more rapid northward migration of the Colorado Plateau towards middle latitudes that was not initiated until the Middle Jurassic. Using this new paleogeographic context, this paper shows that the dominant winds recorded by the Plateau sandstones were not related to mid-latitude northern hemisphere anticyclones (Parrish \& Peterson, 1988; Loope et al., 2001). These winds instead blew across the equator towards an area of low pressure that developed each year in the southern hemisphere during December-JanuaryFebruary, when solar heating there was most intense.
Although cross-equatorial, westerly winds are widespread in today's eastern hemisphere and are prominent in several published numerical models of Pangaean paleoclimate, geological evidence for them has only been reported rarely. Tabor \& Montanez (2002) recently demonstrated that the isotopic composition of pedogenic carbonates in Late Paleozoic paleosols from the south-western USA records transport of moisture from the west, implying a reversal of easterly winds. This paper shows much more direct evidence for this circulation: dunes within the southern parts of the vast sand seas of western Pangaea were shaped and driven by these tropical westerlies.

\section{Mesozoic paleogeography of western Pangaea}

Global-scale maps showing Pangaea during the Early Mesozoic place the Colorado Plateau in a subtropical position (Scotese, 2003). In these reconstructions, magnetic paleopoles determined by studies of rocks in eastern USA are used to constrain the position of North America. Previous attempts to understand Pangaean atmospheric circulation (Parrish \& Peterson, 1988; Dubiel et al., 1991; Loope et al., 2001) have used this paleogeographic context. Two decades of field and laboratory work on the magnetic properties of Early Mesozoic rocks of the Colorado Plateau itself has been carried out by two independent research teams (Steiner, 1983; May \& Butler, 1986; Bazard \& Butler, 1991; Steiner \& Lucas, 2000; Steiner, 2003). These studies show that the Plateau rocks retain low paleomagnetic inclinations and were therefore (like the Permian rocks of the region) deposited quite near the equator (Figure 2). Given that the aeolian sandstones that are the subject of this study are interbedded with the strata that have yielded these low inclinations, this study interprets, for the first time, the paleowind patterns recorded by the Plateau sandstones in the paleogeographic context provided by their directly associated strata (Figure 2).

\section{Paleowind directions}

The migration of large dunes masks short-term climate variations and integrates the spatial effect of climate to a scale similar to that of global climate models (Blumberg \& Greeley, 1996). Figure 2B-F shows paleowind data for the Colorado Plateau (Peterson, 1988) that are based on thousands of dip directions measured from thick sets of Mesozoic and Paleozoic 


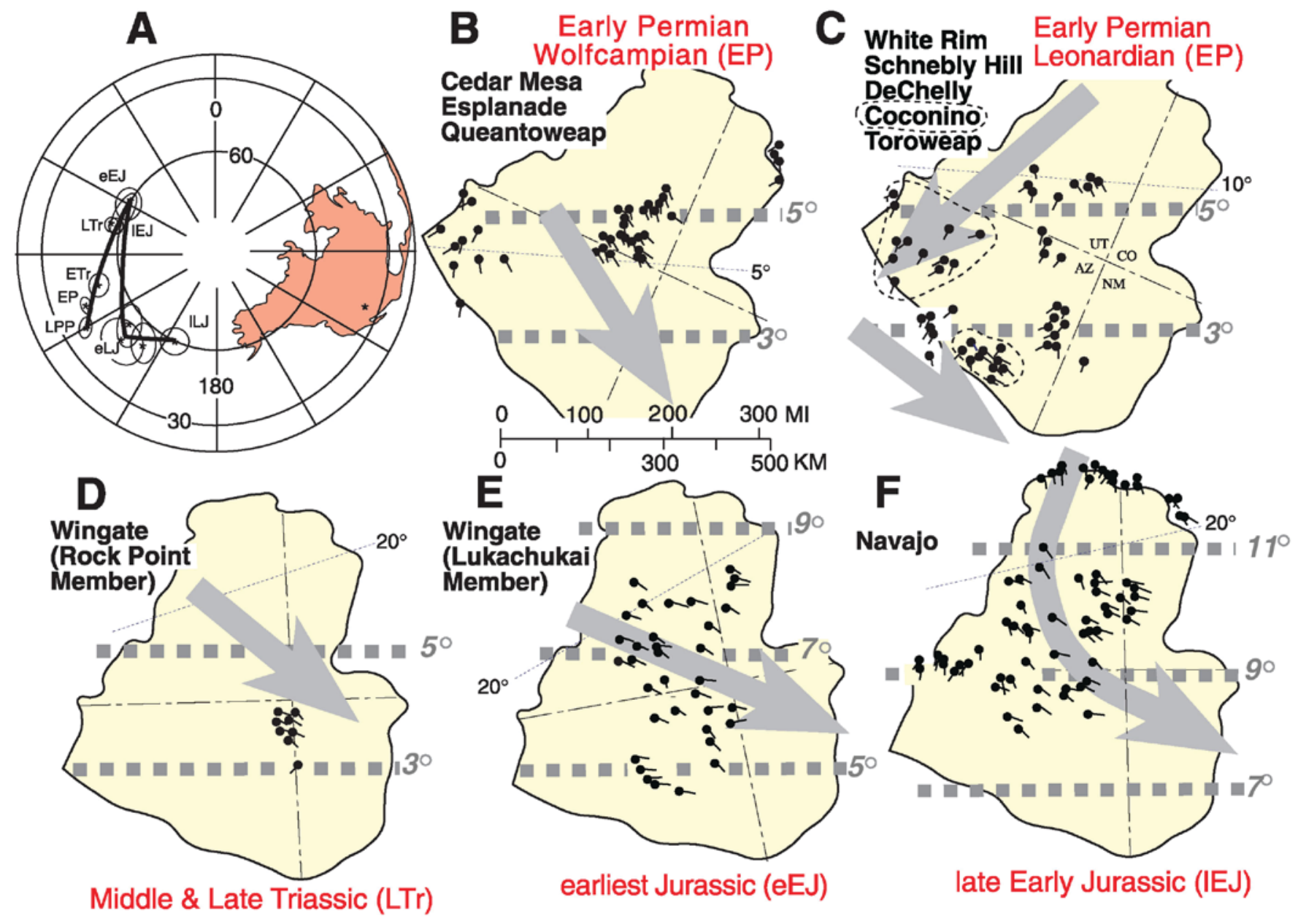

Figure 2. Paleolatitudes and paleowinds of Colorado Plateau aeolian sandstones. (A) Paleomagnetic pole positions for the Colorado Plateau strata deposited between Late Pennsylvanian (LPP) and late Late Jurassic (ILJ) time. Circles represent the area of 95\% confidence around each pole (data are from May \& Butler, 1986; Bazard \& Butler, 1991; Steiner \& Lucas, 2000). (B-F) Paleowind data assembled by Peterson (1988). Lines projecting from dots represent downwind and the resultant dip direction of at least 20 cross-bed sets (Peterson, 1988). Bold dashed lines represent the paleolatitudes corresponding to the paleopoles in (A). Magnetic paleopole used for Permian maps is N50.5 ${ }^{\circ}, \mathrm{E} 110.7^{\circ}$; for Triassic N57. ${ }^{\circ}, \mathrm{E} 66.6^{\circ}$; for earliest Jurassic N58.2 ${ }^{\circ}$, E51.9 ${ }^{\circ}$; for late Early Jurassic N62.1 ${ }^{\circ}$ E70.2 ${ }^{\circ}$. Fine dotted lines are from Peterson (1988). On account of post-Jurassic rotation and translation of crustal blocks within the western US relative to the North American craton (Steiner, 2003), all data reported by Peterson from outside the Plateau region are excluded.

dune cross-strata. The vector mean strengths (consistency factors) for entire formations that are hundreds of metres thick and tens of thousands of square kilometres in extent are high, ranging from 0.75 to 0.94 (Peterson, 1988, Figure 14). As an example, from threedimensional exposures of 260 sets of trough and tabular aeolian cross-strata within Early Permian rocks in south-eastern Utah, Loope (1984) reported a resultant vector of $143^{\circ}$ and a vector mean strength of 0.74 (standard angular deviation of $413^{\circ}$ ). This resultant vector is represented by one of the dozens of arrows on Peterson's (1988, fig, 7; Figure 2B) map. Although the vector mean strength is relatively low compared with values compiled by Peterson (1988), from other aeolian sandstones on the Plateau, Loope (1984) concluded that 'the south-eastward winds did not significantly vary in direction during deposition of the 500 -m-thick sequence'. The directional consistency of the data from the Plateau sandstones probably reflects the abundance of large, simple sets of grainflow crossstrata in these rocks (Kocurek, 1991). The consistency of the data through both time and space demonstrates not only that the aeolian cross-strata of the Colorado Plateau record the direction of prevailing paleowinds, but also that these rocks record a long-lived, planetaryscale atmospheric circulation pattern.

As shown in Figure 2, north-westerly paleowinds persisted for 100 million years, from Early Permian 

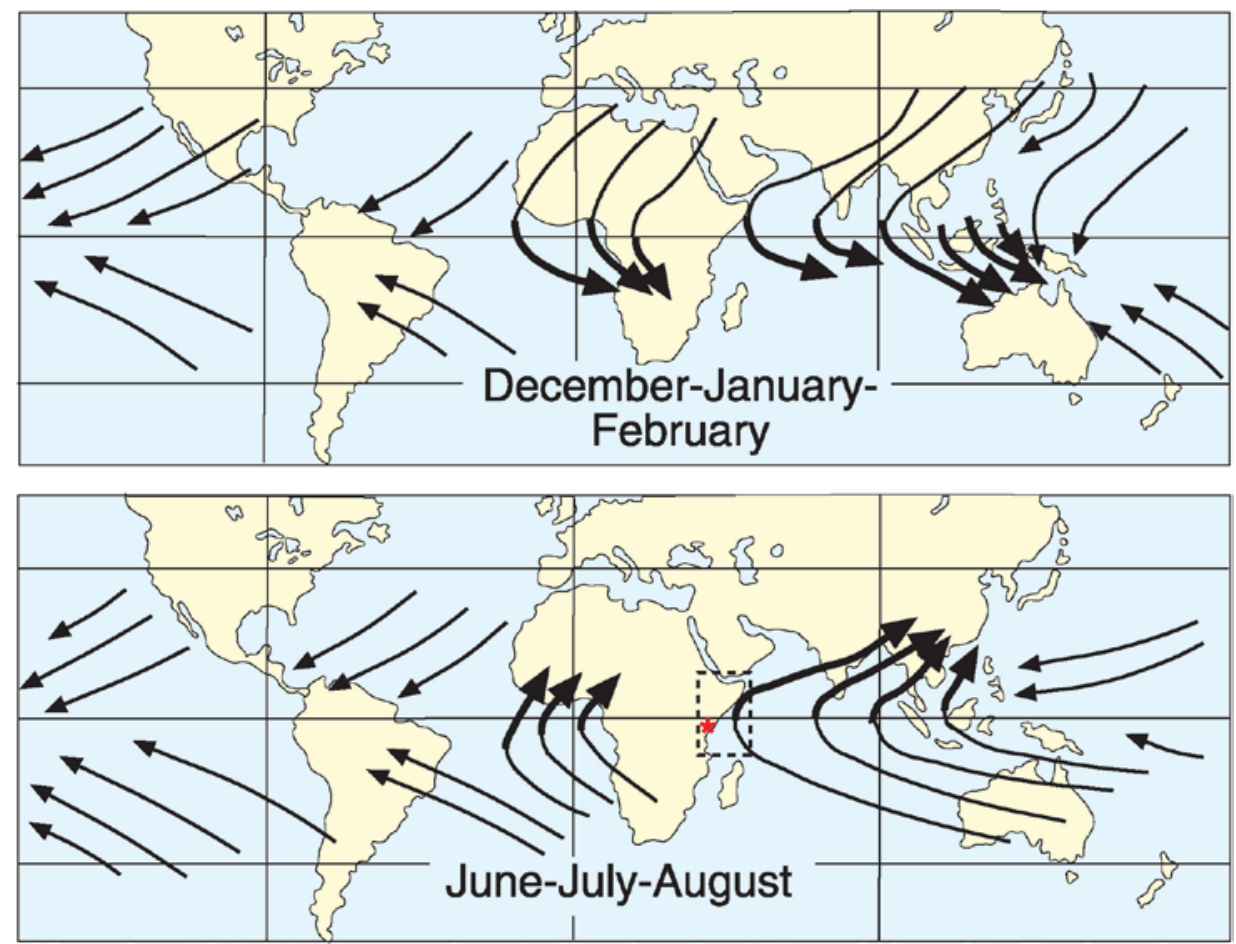

Figure 3. Modern surface winds (modified from Webster, 1987). Within the tropics, westerly winds (bold arrows) are restricted to monsoon systems. Rectangle shows position of East African Low Level Jet; star marks location of Mombasa, Kenya. Note that, in several locations, trade winds are reoriented to westerlies before crossing the equator. to Early Jurassic. The paleowind data in Figure 2B-F are accompanied by both the paleogeographic context originally published by Peterson (1988) and new lines of paleolatitude determined by paleomagnetic studies of coeval rocks on the Plateau (Steiner, 1983; May \& Butler, 1986; Bazard \& Butler, 1991; Steiner \& Lucas, 2000; Steiner, 2003). The invariance of prevailing wind direction through time had been difficult to explain using the previously published continent-scale paleogeographic reconstructions, in which the centre of the Plateau was shown to move from $4^{\circ} \mathrm{N}$ to $18^{\circ} \mathrm{N}$. The new paleolatitudes directly reflect the low magnetic inclinations of Early Mesozoic rocks and show only about $5^{\circ}$ of northward movement. This interpretation of paleography thus fits well with the invariant wind direction recorded by the aeolian strata.

Instead of blowing around seasonally shifting, mid-latitude anticyclones in the northern hemisphere (Parrish \& Peterson, 1988; Dubiel et al., 1991; Loope et al., 2001), the dune-driving paleowinds were tropical north-westerlies (Figure 3; Webster, 1987) that blew across the equator during December-JanuaryFebruary. This interpretation validates most existing models of Pangaean atmospheric circulation (Kutzbach \& Gallimore, 1989; Chandler et al., 1992; Kutzbach, 1994; Gibbs et al., 2002), and the near-equatorial paleogeographic setting helps to explain evidence for heavy rainfall events during dune migration (Loope et al., 2001).

\section{Monsoonal circulation and tropical westerlies}

Tropical westerlies are presently confined to the eastern hemisphere where the monsoon is best developed (Webster, 1987; Figure 3). The convergence brought about by this circulation brings strongly seasonal, heavy rainfall. In June, July and August, as low-level, southern hemisphere trade winds over the Indian Ocean and eastern Atlantic approach the equator, they turn abruptly and flow as tropical westerlies into the low-pressure zones over India and west Africa. North of the equator, these flows from the southwest represent a $180^{\circ}$ reversal of the north-easterly flow that dominates during the winter months. The southern hemisphere has the same seasonal cycle, as the wind flow in December, January and February is opposite that of June, July and August due to the development of low pressure zones in Australia and southern Africa (Figure 3). This reversal of low-level winds is made possible by the weakening of the Coriolis force as air approaches the equator. Under these circumstances, the air is free to move directly towards the thermally induced, low-pressure zones in the opposite hemisphere. When the air moves across the equator into higher latitudes, it is turned by the Coriolis force, thereby completing the flow reversal process (Webster, 1987).

Although several numerical models of Pangaean atmospheric circulation show tropical westerlies (Kutzbach 

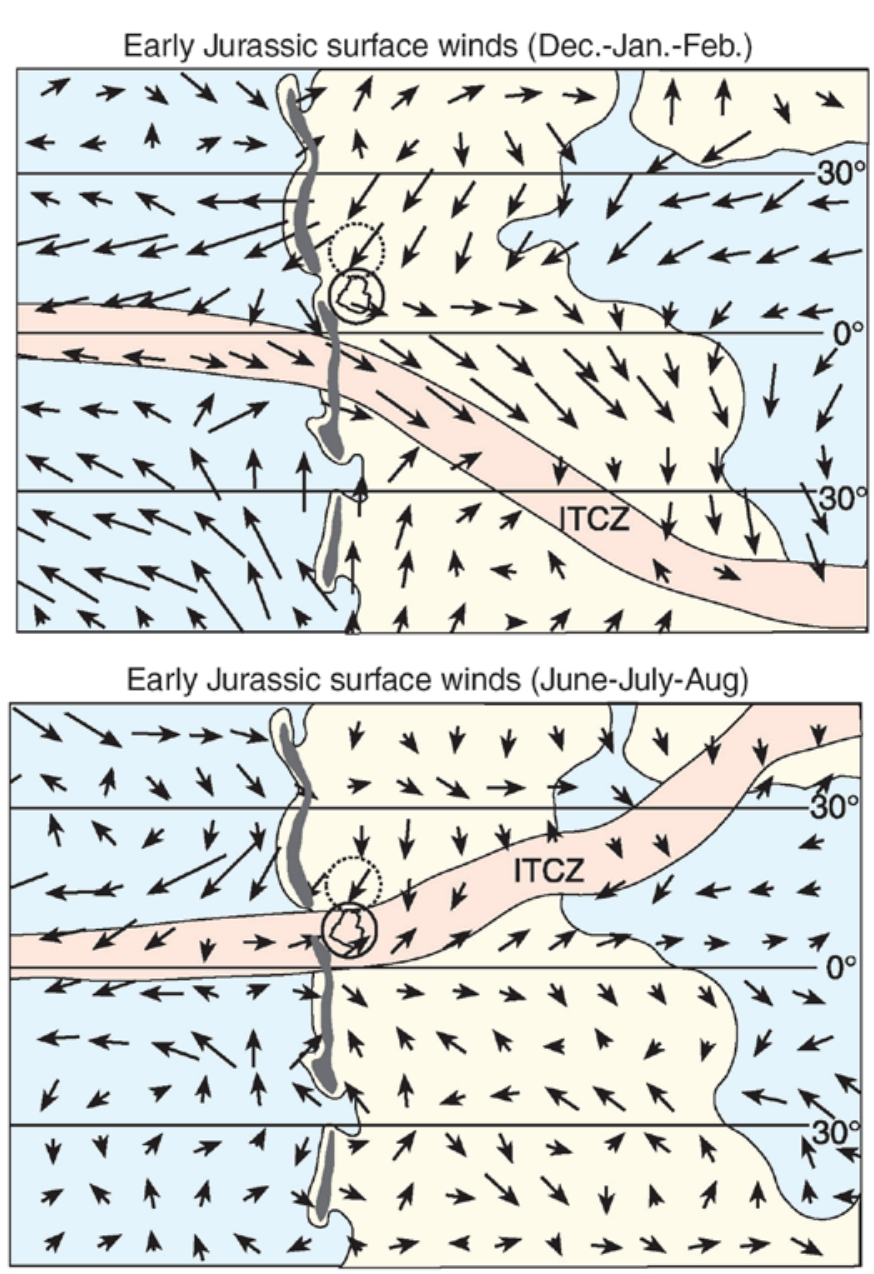

Figure 4. Simulated surface winds from Early Jurassic global climate model of Chandler et al. (1992). Dashed circle shows position of Colorado Plateau in Chandler et al.'s (1992) original figure; solid circle shows the position of the Plateau that reflects recent paleomagnetic data. No other paleogeography has been adjusted. In upper (DJF) panel, note shift of winds from north-easterly to north-westerly in area of Colorado Plateau and the position of mountains just to the west of the Plateau (light shading). In lower panel, note migration of Intertropical Convergence Zone over Plateau during June, July and August.

\& Gallimore, 1989; Chandler et al., 1992; Kutzbach, 1994; Gibbs et al., 2002), the Early Jurassic model by Chandler et al. (1992) is of special interest because it shows subtropical north-easterlies (trade winds) shifting to become tropical north-westerlies at about $10^{\circ}$ north of the paleoequator (Figure 4), a circulation very close to that shown by the replotted paleowinds of the Navajo Sandstone (compare Figure 2F with top part of Figure 4). The greater roughness of land relative to sea surfaces allowed north-easterly trade winds over Pangaea's interior to start flowing at a higher angle to isobars as they approached the equator. Because the Co- riolis force goes to zero at the equator, such flows can become westerly while still as much as $10^{\circ}$ poleward of the equator (Figure 4).

Earlier interpretations of the paleowind directions recorded by cross-strata within the Navajo Sandstone relied upon seasonal north-south shifts of the anticyclone along the western coast of Pangaea. Parrish \& Peterson (1988) interpreted the dominant north-westerly flow as the June-July-August circulation, whereas Loope et al. (2001) hypothesized that the north-westerlies were drawn southwards to at least $18^{\circ} \mathrm{N}$ during December-January-February (further south than in any modern setting). The paleomagnetically derived paleogeography presented here disposes of the need to bring westerlies southwards from the mid-latitudes because tropical westerlies are widespread today near the equator. It is not yet clear how far from the equator westerly flows can occur. Pangaean global climate models have simulated westerly flows as much as $10^{\circ}$ from the equator (Chandler et al., 1992), but it seems unlikely that this circulation could have been dominant as much as $18^{\circ}$ from the equator.

\section{Paleowind strength}

Although the more southerly position of the Colorado Plateau during Early Jurassic time helps to explain the paleowind directions recorded by late Early Jurassic Navajo Sandstone cross-strata, it raises another issue: paleowind strength. Depositional cycles composed of couplets of grainflow-dominated and wind ripple-dominated cross-strata are prominent within parts of the Navajo Sandstone in southern Utah and northern Arizona, and record rhythmic shifts in wind strength and direction (Hunter \& Rubin, 1983; Chan \& Archer, 1999; Loope et al., 2001). Within these depositional cycles, sand carried by the northwesterly wind and deposited by dry grainflows on the dunes' south-east-facing leefaces makes up about $80 \%$ of the preserved cross-strata. Because the deposits of opposing winds diminish rapidly with height above the dune base, and because the basal parts of dunes are preferentially preserved, an even higher proportion of the sand within the original bedforms was probably deposited by the dominant north-westerly winds. After showing that the depositional cycles are too thick to represent daily cycles in wind energy and direction, Hunter \& Rubin (1983) argued convincingly for an annual origin for the cycles. They showed that wind regimes in several parts of the modern world are moving large dunes more than $1 \mathrm{~m}$ per year, and concluded 
that the north-westerlies that prevailed during deposition of the cycles within the Navajo Sandstone (near the western edge of the Colorado Plateau) were therefore 'quite modest, and the sand may not have moved during many days of the year' (Hunter \& Rubin, 1983, p. 451).

If, however, the paleogeographic and paleoclimatic interpretations presented here are correct, the annual duration of the prevailing Early Jurassic winds (during which all net dune migration took place) was 5 months or less (November-March), and the setting was tropical, not subtropical. Today, winds are light and infrequent in nearly all near-equatorial settings. During northern hemisphere monsoons (June-July-August), however, winds forming the core of the East African Low Level Jet are strong and steady. The jet is centred over the equator, and the core (winds in excess of $10 \mathrm{~m} \mathrm{~s}^{-1}$ ) is about $500 \mathrm{~km}$ wide (Findlater, 1969). The jet is positioned west and equatorward of the zone of low atmospheric pressure that develops each summer over south Asia (Figure 3). The strongest flow is concentrated against the highlands of Ethiopia and Kenya (Findlater, 1969). Within just $5^{\circ}$ of the equatorial circumference, almost $65 \%$ of the total mean lowlevel cross-equatorial transport is achieved (Rodwell \& Hoskins, 1995).

Modelled fluctuations of temperature and pressure for Pangaea are very large (Crowley et al., 1989; Kutzbach \& Gallimore, 1989). The position of the Colorado Plateau west and equatorward of the summertime (December-January-February) thermal low in the southern hemisphere and its location just to the east of Pangaea's mountainous western coast (Figure 4) are indications that the Jurassic DecemberJanuary-February paleowinds over western Pangaea (northern hemisphere) are analogous in important ways to the modern June-July-August wind regime of eastern Africa just south of the equator. The scale and structure of annual depositional cycles in parts of the Navajo Sandstone, however, indicate that, during at least a short interval within the Early Jurassic, December-January-February winds were stronger and steadier than the strongest, steadiest, cross-equatorial surface airflow in the modern world. Where the East African Low Level Jet comes onshore at Mombasa, Kenya (Figure 3), the annual sand drift potential for all winds is 105 units (see Fryberger \& Dean, 1979). The total for the north-west monsoon (MaySeptember) is 37 units. According to the classification of the wind regimes of global sand seas (Fryberger \& Dean, 1979), these values place Mombasa in the lower part of the "low wind energy environment." In July, the maximum mean surface wind speed under the jet is over the western Indian Ocean off Somalia at 15 knots (7.7 $\mathrm{m} \mathrm{s}^{-1}$; Findlater, 1969). Using this figure for the full period of the northern monsoon, the sand drift potential is 280 units, an 'intermediate wind energy environment' that is well below the cutoff (400 units) for a 'high wind energy environment' (Fryberger \& Dean, 1979). One of the few places where large dunes move at rates comparable to those that generated the annual depositional cycles in the $\mathrm{Na}-$ vajo Sandstone is the coast of southern Africa. The wind there is onshore nearly year round, producing the highest known drift potential of any modern setting where aeolian sand is accumulating, nearly 3000 units (Fryberger \& Dean, 1979). Despite accumulating very near the equator at a time when the earth was essentially free of glacial ice and warm seas extended to the poles (Chandler et al., 1992), parts of the Navajo Sandstone record a wind regime that, at least during several months of the year, was comparable to the strongest modern, dune-associated wind regimes. Although the Jurassic GCM of Chandler et al. (1992) shows stronger surface north-westerlies in western Pangaea during December-January-February than other Pangaean models, north-easterly surface (trade) winds flow uninterrupted across the western mountains in their simulation. The large grid size used in this model required a highly smoothed representation of topography that may have subdued any blocking effect, and thereby diminished wind speeds in western Pangaea.

Airflows within the East African Low Level Jet reverse seasonally, and the position of the jet is fixed. The Thar Desert of India and Pakistan lies north-east of the jet at $25-29^{\circ} \mathrm{N}$ and has a bimodal wind regime: flow is north-easterly in December-January-February and south-westerly in June-July-August (Fryberger \& Dean, 1979). Net dune migration is towards the north-east because south-westerly flow is stronger and steadier. For Pangaea during the Early Jurassic, the scale and geometry of the Navajo Sandstone depositional cycles require that June-July-August southerly flows were very weak relative to the dunedriving, north-westerly (December-January-February) winds. The Late Triassic has been considered the time when Pangaea was symmetrical about the equator (Parrish \& Peterson, 1988; Dubiel et al., 1991; Parrish, 1993). With the new paleogeographic reconstruction (Figure 2D), more of the supercontinent lies south of the equator than north, implying a stronger austral monsoon. The marked asymmetry in wind strength recorded by the Navajo Sandstone, however, could al- 
ternatively be a result of regional rather than globalscale phenomena. In contrast to the in-place reversal exhibited by the East African Jet, two spatially distinct zones of trade wind reorientation developed on opposite sides of Pangaea's equator, about $15^{\circ}$ of latitude (more than $1500 \mathrm{~km}$ ) apart, as shown in the Early Jurassic model of Chandler et al. (1992; Figure 4). Because of this separation, the western Colorado Plateau was not in the path of directly opposing flows during June-July-August.

Although cross-equatorial flows from the southern hemisphere during June-July-August may have left behind few or no cross-strata on the Colorado Plateau before the Late Jurassic, they transported considerable dust (Soreghan et al., 2002), and are significant to discussion of the older strata in two important ways. In order for sand to accumulate and achieve long-term preservation, sand influx to a subsiding sedimentary basin must exceed outflux. Sand seas therefore typically occupy areas with decelerating or opposing winds. Southerly winds (June-July-August) played a crucial role in maintaining a positive sand budget in western Pangaea. Further, more southerly winds, possibly with velocities below the threshold of sand movement, delivered the moisture for the annual monsoonal rains that slumped avalanche faces (Loope et al., 2001) and sustained interdune ecosystems (Winkler et al., 1991; Eisenberg, 2003; Loope \& Rowe, 2003) during pluvial episodes of Navajo Sandstone deposition. The Chandler et al. (1992) model for June-JulyAugust shows that the Intertropical Convergence Zone migrates to $10^{\circ} \mathrm{N}$ over western Pangaea - directly over the Colorado Plateau, if the Plateau is shifted to fit with the new paleomagnetic evidence (Figure 4). Such an annual migration fits well with evidence for high seasonality of rainfall reported from the Upper Triassic Chinle Formation (Dubiel et al., 1991).

\section{Conclusions}

On the Early Jurassic paleogeographic map by Scotese (2003), the southern edge of the Colorado Plateau sand sea is shown to be analogous to the southern edge of the modern Sahara, at the northern limit of the ITCZ migration. The reconstruction presented here places the dune deposits considerably further south, in a near-equatorial region that would have been directly under the ITCZ for several months each year. That large, active dunes persisted in this setting testifies to the strength of the cross-equatorial winds and the efficacy of the rain shadow along Pangaea's western coast.
The near-equatorial, north-westerly winds blew only during the summer months of the southern hemisphere (December-January-February), but at times were sufficiently powerful to drive large dunes more than $1 \mathrm{~m}$ year $^{-1}$. Wind direction reversed at the onset of the northern summer (June-July-August), and southerly flows were probably important to the maintenance of a positive sand budget for the depositional basin.

When placed in their proper paleogeographic context, dip directions from Colorado Plateau aeolian sandstones provide important clues to planetary-scale atmospheric circulation during much of Pangaea's existence. Aeolian cross-strata should receive more attention in future paleogeographic and paleoclimatic reconstructions.

\section{Acknowledgments}

We thank Joe Mason, Robert Butler, Rob Van der Voo and Chris Scotese for helpful discussions. Lynn Soreghan and Philip Allen reviewed the manuscript and provided useful suggestions. This work was supported by the Schultz Chair in Stratigraphy at University of Nebraska, and by a grant from the National Science Foundation (EAR02-07893) to Loope, Rowe and Lancaster.

\section{References}

Bazard, D.R. and Butler, R.F. (1991) Paleomagnetism of the Chinle and Kayenta Formations, New Mexico and Arizona. J. Geophys. Res., 96, 9847-9871.

Blakey, R.C., Peterson, F. and Kocurek, G. (1988) Synthesis of late Paleozoic and Mesozoic aeolian deposits of the Western Interior of the United States. Sed. Geol., 56, 3-125.

Blumberg, D.G. and Greeley, R. (1996) A comparison of general circulation model predictions to sand drift and dune orientations. J. Climate, 9, 3248-3259.

Chan, M.A. and Archer, A.W. (1999) Spectral analysis of eolian foreset periodicities: implications for Jurassic decadal-scale paleoclimatic oscillators. Paleoclimates, 3, 239-255.

Chandler, M., Rind, D. and Ruedy, R. (1992) Pangaean climate during the Early Jurassic: GCM simulations and the sedimentary record of paleoclimate. Bull. Geol. Soc. Am., 104, 543-559.

Crowley, T.J., Hyde, W.T. and Short, D.A. (1989) Seasonal cycle variations on the supercontinent of Pangaea. Geology, 17, 457-460.

Dubiel, R.F., Parrish, J.T., Parrish, J.M. and Good, S.C. (1991) The Pangaean megamonsoon: evidence from the Upper Triassic Chinle Formation. Palaios, 6, 347-370.

Eisenberg, L. (2003) Giant stromatolites and a supersurface in the Navajo Sandstone, Capitol Reef National Park, Utah. Geology, 31, 111-114. 
Findlater, J. (1969) Interhemispheric transport of air in the lower troposphere over the western Indian Ocean. Q. J. Roy. Meteorol. Soc., 95, 400-403.

Fryberger, S.G. and Dean, G. (1979) Dune forms and wind regime. In: A Study of Global Sand Seas (Ed. E.D.McKee), US Geol. Surv. Prof. Paper, 1052, 137-169.

Gibbs, M.T., Rees, P.M., Kutzbach, J.E., Ziegler, A.M., Behling, P.J. and Rowley, D.B. (2002) Simulations of Permian climate and comparisons with climate-sensitive sediments. J. Geol., 110, 33-55.

Harland, W.B., Armstrong, R.L., Cox, A.V., Craig, L.E., Smith, A.G. and Smith, D.G. (1989) A Geologic Time Scale. Cambridge University Press, 263 pp.

Hunter, R.E. and Rubin, D.M. (1983) Interpreting cyclic crossbedding, with an example from the Navajo Sandstone. In: Aeolian Sediments and Processes (Eds M.E.Brookfield and T.S. Ahlbrandt), pp. 429-454. Elsevier, Amsterdam.

Kocurek, G. (1991) Interpretation of ancient aeolian sand dunes. Annu. Rev. Earth Planet. Sci., 19, 43-75.

Kutzbach, J.E. (1994) Idealized Pangaean climates: sensitivity to orbital change: in Pangaea. Paleoclimate, Tectonics, and Sedimentation During Accretion, Zenith, and Breakup of a Supercontinent (Ed. G.D.Klein), Geol. Soc. Am. Spec. Paper, 288, 41-55.

Kutzbach, J.E. and Gallimore, R.G. (1989) Pangaean climates: megamonsoons of the megacontinent. J. Geophys. Res., 94, 3341-3357.

Loope, D.B. (1984) Eolian origin for upper Paleozoic sandstones, southeastern Utah. J. Sed. Petrol., 54, 563-580.

Loope, D.B. and Rowe, C.M. (2003) Long-lived pluvial episodes during deposition of the Navajo Sandstone. J. Geol., 111, 223-232.

Loope, D.B., Rowe, C.M. and Joeckel, R.M. (2001) Annual monsoon rains recorded by Jurassic dunes. Nature, 412, 64-66.

May, S.R. and Butler, R.F. (1986) North American Jurassic apparent polar wander - implications for plate motions, paleogeography and Cordilleran tectonics. J. Geophys. Res., 91, 11,519-11,544.

Parrish, J.T. (1993) Climate of the supercontinent Pangaea. J. Geol., 101, 215-233.
Parrish, J.T. and Peterson, F. (1988) Wind directions predicted from global circulation models and wind directions determined from aeolian sandstones of the western United States. Sed. Geol., 56, 261-282.

Peterson, F. (1988) Pennsylvanian to Jurassic aeolian transportation systems in the western United States. Sed. Geol., 56, 207-260.

Rodwell, M.J. and Hoskins, B.J. (1995) A model of the Asian summer monsoon. Part II: cross-equatorial flow and pv behavior. J. Atmos. Sci., 52, 1341-1356.

Scotese, C.R. (2003) PALEOMAP, Earth History, Jurassic. [WWW document]. URL http://wWw.scotese.com/jurassic.htm (April 2003).

Soreghan, M.J., Soreghan, G.S. and Hamilton, M.A. (2002) Paleowinds inferred from detrital-zircon geochronology of upper Paleozoic loessite, western equatorial Pangaea. Geology, 30, 695-698.

Steiner, M.B. (1983) Mesozoic apparent polar wander and plate motions of North America. In: Mesozoic Paleogeography of the West-Central United States: Rocky Mountain Paleogeography Symposium 2 (Eds M.W.Reynolds and E.D. Dolly), SEPM Rocky Mtn Section, pp. 1-11.

Steiner, M.B. (2003) A cratonic middle Jurassic paleopole: Callovian-Oxfordian pole stillstand (J-2 cusp), rotation of the Colorado Plateau, and Jurassic North American apparent polar wander. Tectonics, 22, article no.1020.

Steiner, M.B. and Lucas, S.G. (2000) Paleomagnetism of the Late Triassic Petrified Forest Formation, Chinle Group, western United States: Further evidence of 'large' rotation of the Colorado Plateau. J. Geophys. Res., 105, 25,791-25,808.

Tabor, N.J. and Montanez, I.P. (2002) Shifts in late Paleozoic atmospheric circulation over western equatorial Pangaea: Insights from pedogenic mineral delta O-18 compositions. Geology, 30, 1127-1130.

Webster, P.J. (1987) The elementary monsoon. In: Monsoons (Eds J.S.Fein and P.L. Stephens), pp. 3-32. John Wiley \& Sons, New York.

Winkler, D.A., Jacobs, L.L., Congleton, J.D. and Downs, W.R. (1991) Life in a sand sea: biota from Jurassic interdunes. Geology, 19, 889-892. 